\section{ANALYSIS OF ARTOCARPUS HETEROPHYLLUS PEEL AS A NATURAL COAGULANT USING RESPONSE SURFACE METHODOLOGY (RSM)}

\author{
M. Priyatharishinia, N. M. Mokhtara,b*
}

aFaculty of Civil Engineering Technology, College of Engineering Technology, Universiti Malaysia Pahang, Lebuhraya Tun Razak 26300 Kuantan, Pahang, Malaysia

bEarth Resources and Sustainability Center, Universiti Malaysia Pahang, Lebuhraya Tun Razak 26300 Kuantan, Pahang, Malaysia
Article history

Received

3 December 2019

Received in revised form

12 May 2020

Accepted

20 May 2020

Published online

22 June 2020

*Corresponding author nadzirah@ump.edu.my

\section{Graphical abstract}

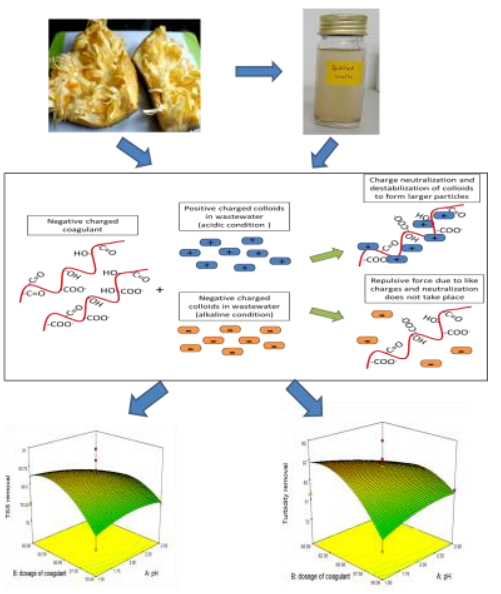

\section{Abstract}

The chemical coagulants used in the process of wastewater treatment causes negative implications on environment and human health. Exploration on natural coagulants as environmental friendly solution has been widely carried out. In present research, Artocarpus heterophyllus (jackfruit) peel is used as coagulant in treating domestic wastewater. This study aimed to assess optimum $\mathrm{pH}$ of wastewater and coagulant dosage by varying them to achieve the maximum removal rate of total suspended solid (TSS), biological oxygen demand (BOD), chemical oxygen demand (COD) and turbidity. The studied range for $\mathrm{pH}$ of wastewater was $\mathrm{pH} 1-3$ and dosage of coagulant within 50-70 mg/L. Response surface methodology (RSM) based on central composite design (CCD) implied in optimization of this coagulation process. Treatment using this natural coagulant enabled maximum reduction of turbidity, TSS, BOD and COD up to $80.7 \%, 77.5 \%, 34.3 \%$ and $34.6 \%$ respectively under optimum condition of $\mathrm{pH} 2.1$ and dosage of $58 \mathrm{mg} / \mathrm{L}$. These findings revealed higher reduction in turbidity and TSS. Thus, this study indicates the promising potential of the Artocarpus heterophyllus peel extract as an alternative bio-based coagulating agent for effective pre-treatment of wastewater.

Keywords: Domestic wastewater, plant-based coagulant, Artocarpus heterophyllus optimization, coagulation

\begin{abstract}
Abstrak
Bahan penggumpal kimia yang digunakan dalam rawatan air sisa memberi kesan negatif terhadap alam sekitar dan kesihatan manusia. Keberkesanan bahan penggumpal semula jadi sebagai penyelesaian mesra alam semakin banyak diterokai dan dikaji. Dalam kajian ini, ekstrak kulit Artocarpus heterophyllus (nangka) digunakan sebagai bahan penggumpal dalam merawat air sisa domestik. Kajian ini bertujuan menilai $\mathrm{pH}$ air sisa dan dos koagulan yang optimum untuk mencapai kadar penyingkiran maksimum bagi pepejal terampai (TSS), keperluan oksigen biologi (BOD), keperluan oksigen kimia (COD) dan kekeruhan. Kaedah gerak balas permukaan (RSM) berdasarkan reka bentuk komposit pusat (CCD) digunakan dalam pengoptimuman proses penggumpalan. Proses rawatan menggunakan bahan penggumpal semula jadi ini membolehkan pengurangan maksimum kekeruhan, TSS, BOD dan COD sebanyak $80.7 \%, 77.5 \%, 34.3 \%$ dan $34.6 \%$ masing- masing dicapai pada pH 2.1 dan dos sebanyak $58 \mathrm{mg} / \mathrm{L}$. Justeru, kajian ini membuktikan ekstrak kulit Artocarpus heterophyllus berpotensi sebagai bahan penggumpal semula jadi dalam rawatan awal air sisa.

Kata kunci: Air sisa domestik, bahan penggumpal semula jadi, Artocarpus heterophyllus, pengoptimuman, penggumpalan
\end{abstract}

(C) 2020 Penerbit UTM Press. All rights reserved 


\subsection{INTRODUCTION}

Coagulation involves two-step chemical process to remove suspended or colloidal particles by firstly reducing the zeta potential below the Van der Waal's attractive forces followed by aggregation of micelles to form clumps which agglomerate colloidal particles [1]. In this process, chemical or inorganic coagulants has been broadly used as coagulants in treatment of various types of wastewater based on their effective performance, wider availability and cost-effectiveness [2]. However, these chemicalbased coagulants possess certain disadvantages such as relatively high procurement costs as well as detrimental effects on human health and environment as well as large production of sludge [35]. The efficiency of coagulation process in wastewater treatment is influenced by few factors which include $\mathrm{pH}$ of wastewater and dosage of coagulant. The $\mathrm{pH}$ of wastewater influences the solubility of the coagulant and charge on the organic matter particles. In terms of dosage, under dosing or overdosing of the coagulants will reduce the efficiency of the coagulation process [6-7]. These factors are among the important parameters that should be monitored and controlled to achieve maximum performance of the coagulants in wastewater treatment.

Factors of coagulation process can be studied or analysed by using the application of either onefactor-at-a-time (OFAT) or response surface methodology (RSM) technique. However, OFAT method limits the researcher in studying interactive effects of independent variables. Optimum value of more than one parameters that works in maximizing yield is difficult to be identified as the rest is kept constant. The RSM is a methodical approach to optimize by modelling and analysing effects of different parameters in respective of desired responses. RSM assists in determining the operational conditions which is optimum for the system or to identify a domain in which operating specifications are convinced [8-9]. RSM can be implemented within wide range of processes in achieving the highest efficiency by method of optimization [10]. Coagulation process is influenced by various factors and among them are $\mathrm{pH}$ of wastewater and dosage of coagulant which are the focus of this study. The $\mathrm{pH}$ of wastewater affects the chemistry of the coagulant in terms of solubility and charge of the natural organic matter particles. The $\mathrm{pH}$ must be controlled as the coagulation process takes place within a specific range for respective coagulants [6]. On the other hand, desired dosage of the coagulant is also an important process-control factor. The optimum coagulant dosage is necessary to assure the effectiveness in retaining the quality of settled wastewater [7]. Thus, these two factors were emphasized in this experiment to determine their influence in effectiveness of plant-based coagulant.

Recent studies have been carried out on optimization of coagulation process using plant- based coagulant by RSM application [11-13, 3]. Tawakkoly et al. have applied CCD in their study of using Salvia hispanica seed in treating landfill leachate by optimizing dosage of coagulant and $\mathrm{pH}$ of wastewater [3]. Rice husk ash and Opuntia ficusindica have also been evaluated in their capability of removing pollutants in palm oil effluent and tailings pond water respectively by optimization of method [13-14]. Other natural coagulants such as Moringa oleifera and Cassia obtusifolia gum seed were also analysed in their capability of treating wastewater with assistance of CCD method to identify interaction of different factors which influenced their performance $[8,15]$. To the best of our knowledge, optimization on Artocarpus heterophyllus peel as coagulant in wastewater treatment have not been studied. Thus, RSM was studied to maximize the efficiency of the coagulant with CCD in this study by analysing the effects of interaction between process factors. The statistical design comprised of two process factors which are dosage of coagulant and $\mathrm{pH}$ of wastewater for turbidity, total suspended solid (TSS), biological oxygen demand (BOD) and chemical oxygen demand (COD) responses.

\subsection{METHODOLOGY}

\subsection{Materials}

Artocarpus heterophyllus peels which is the jackfruit peel were extracted from mature fruits collected from fruit stall located in the city of Gambang, Pahang, Malaysia. Analytical-grade hydrochloric acid $(\mathrm{HCl})$ and sodium hydroxide $(\mathrm{NaOH})$ were purchased from Fisher Scientific Malaysia. A packet of pelleted dry cat food (450g) of a commercial brand, Whiskas ${ }^{\circledR}$ (Ocean Fish Flavour) were purchased from hypermarket located in Kuantan, Pahang, Malaysia. The expiration date of the cat food was also considered to ensure no expired cat food being used in the experiment.

\subsection{Preparation of Natural Coagulant from Artocarpus heterophyllus Peel}

The Artocarpus heterophyllus peels were washed thoroughly with distilled water to remove any impurities and cut into pieces of size $4 \mathrm{~cm}$ to $5 \mathrm{~cm}$. The peels were dried in the oven (Memmert Model 30 , Germany) for 48 hours at $60^{\circ} \mathrm{C}$. The dried fruit peels were grinded into fine powder and sieved to a particle size of $0.5 \mathrm{~mm}$. Then, $0.5 \mathrm{~g}$ of the dried raw materials was soaked in distilled water of $100 \mathrm{ml}$ and stirred for 1 hour at $120 \mathrm{rpm}$. This experiment is carried out at room temperature of $25^{\circ} \mathrm{C}$. Muslin cloth was used to filter the suspension and the filtered extract was used in the experiments. 


\subsection{Preparation of Synthetic Domestic Wastewater}

The synthetic domestic wastewater was prepared by dissolving 10 grams of grinded commercial cat food into $1 \mathrm{~L}$ of tap water to imitate the medium strength of domestic wastewater [16-17]. The nutritional composition of this cat food comprised of $30 \%$ crude protein, $10 \%$ crude fat, $5 \%$ crude fibre and $12 \%$ moisture. The properties of the prepared synthetic domestic wastewater were characterized based on different parameters following the APHA method as shown in Table 1. Synthetic domestic wastewater is being used in this study in order to control the properties of wastewater.

Table 1 Characteristics of $10 \mathrm{~g} / \mathrm{L}$ of dissolved cat food

\begin{tabular}{ccc}
\hline Parameter & $\begin{array}{c}\text { Value } \\
\text { (mg/L) }\end{array}$ & $\begin{array}{c}\text { Value of domestic } \\
\text { wastewater }(\mathbf{m g} / \mathbf{L}) \\
{[\mathbf{1 8}]}\end{array}$ \\
\hline $\mathrm{BOD}$ & 300 & 190 \\
$\mathrm{COD}$ & 1500 & 430 \\
$\mathrm{TSS}$ & 216 & 210 \\
$\mathrm{NH}_{3}-\mathrm{N}$ & 15 & 25 \\
$\mathrm{NO}_{3}-\mathrm{N}$ & 27 & 40 \\
Phosphorus & 42 & 7 \\
\hline
\end{tabular}

\subsection{Coagulation Test Experiments}

Coagulation test experiments were performed by jar floc test method with six-paddle rotor jar test equipment (JLT6 Velp Scientifica, Italy). Beakers comprised of $500 \mathrm{~mL}$ synthetic domestic wastewater and the desired amount of coagulant are prepared for the coagulation test. The jar test was conducted at room temperature of $25{ }^{\circ} \mathrm{C}$. In this experiment, different $\mathrm{pH}$ of wastewater was tested in the range of $\mathrm{pH} 1$ to $\mathrm{pH} 3$ and dosage of coagulant within range of $50 \mathrm{mg} / \mathrm{L}$ to $70 \mathrm{mg} / \mathrm{L}$. The $\mathrm{pH}$ of wastewater is controlled by adding 1.0 M HCl and $1.0 \mathrm{M} \mathrm{NaOH}$ and the analyses were done in triplicate. The suspension was stirred at $100 \mathrm{rpm}$ for 4 minutes of rapid mixing and followed by 25 minutes of slow mixing at $40 \mathrm{rpm}$. This is to ensure flocs particles to suspend uniformly. The mixture was left for one hour to allow settling and the sample was filtered with muslin cloth. The supernatant collected was used in the analysis of water quality parameters including turbidity, TSS, COD and BOD. The turbidity was measured using a portable turbidimeter (LaMotte, USA) based on APHA Standard Method 8237. The TSS was performed with vacuum filtration apparatus. The BOD was measured according to APHA Standard Method 8043 using dissolved oxygen (DO) meter. The COD was measured using COD digester (HACH DRB200) and spectrophotometer (HACH DR2400) based on APHA Standard Method 8000 . The removal percentage of these parameters were calculated based on the Equation (1):

$$
\text { Removal }(\%)=\frac{C_{i} C_{f}}{C_{i}} \times 100
$$

In which $C_{i}$ represents initial concentration (mg/L) and $\mathrm{C}_{\mathrm{f}}$ represents final concentration $(\mathrm{mg} / \mathrm{L}$ ) for TSS, COD and BOD whereas turbidity is measured in the unit of NTU.

\subsection{Design of Experiment and Statistical Analysis of Synthetic Domestic Wastewater}

RSM was applied to study the effect of two different parameters which were $\mathrm{pH}$ of wastewater and dosage of coagulant. The removal of turbidity, TSS, BOD and COD were the responses investigated in this study. The stated range was identified from our preliminary study before carrying out RSM to optimize these parameters and identify optimum condition in which the coagulant works the best. In the preliminary study, jar test experiment was carried out where the range applied for $\mathrm{pH}$ of wastewater was 212 and dosage of coagulant was $20-120 \mathrm{mg} / \mathrm{L}$. The efficiency of the coagulant was found lied within the range of 1-3 for the $\mathrm{pH}$ whereas $50-70 \mathrm{mg} / \mathrm{L}$. Thus, this range was chosen to further optimized and find the best condition. Table 2 showed the CCD experimental design that was obtained from Design Expert 7.1.6 (State-Ease, Inc) software. The number of experiments obtained were 13. Investigation on the effects of parameters were studied in the form of quadratic polynomial model.

Table 2 CCD Experimental Design

\begin{tabular}{ccc}
\hline Standard order & $\begin{array}{c}\text { Factor } \mathbf{1} \\
\mathbf{A}: \mathbf{p H}\end{array}$ & $\begin{array}{c}\text { Factor 2 } \\
\text { B: dosage of } \\
\text { coagulant }\end{array}$ \\
\hline 1 & 1.50 & 65.00 \\
2 & 1.50 & 55.00 \\
3 & 2.00 & 60.00 \\
4 & 2.00 & 70.00 \\
5 & 2.00 & 60.00 \\
6 & 2.50 & 65.00 \\
7 & 2.50 & 55.00 \\
8 & 2.00 & 50.00 \\
9 & 1.00 & 60.00 \\
10 & 2.00 & 60.00 \\
11 & 3.00 & 60.00 \\
12 & 2.00 & 60.00 \\
13 & 2.00 & 60.00 \\
\hline
\end{tabular}

\subsection{Characterization of Coagulant}

The infrared spectra of the jackfruit peel extracted with distilled water was recorded using Fourier Transform Infrared (FTIR) (Perkin Elmer Spectrum 100, US) from $400 \mathrm{~cm}^{-1}$ to $4000 \mathrm{~cm}^{-1}$ to study on the functional group existing in the coagulant extract. Zeta potential was measured at a constant temperature of $25^{\circ} \mathrm{C}$ using zeta analyser (Malvern Zetasizer Nano ZS Series, UK) which is a light scattering equipment to identify the surface charges of the coagulant extract. 


\subsection{RESULTS AND DISCUSSION}

\subsection{Model Fitting and ANOVA}

The analysis of variance (ANOVA) for each response is illustrated in Table 4 with important terms including degree of freedom (df), Fischer's value (F-value), probability value (p-value), $\mathrm{pH}$ of wastewater (A), dosage of coagulant (B), coefficient variance (C.V.), square of the correlation coefficient $\left(R^{2}\right)$, adequate precision (adeq. precision) and correlation total (Cor Total).

\subsubsection{Turbidity Reduction}

The turbidity reduction achieved by using the variables design array are represented as in Table 3. The experimental data fitting was investigated with different models which include linear, quadratic, cubic ones and two factorial along with subsequent ANOVA. The results obtained clearly indicate that the most suitable model for reduction of turbidity was a quadratic polynomial model. The coded factors equation of the model is stated in Equation (2):

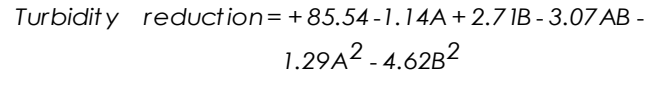

$$
1.29 A^{2}-4.62 B^{2}
$$

Where $A$ is the $\mathrm{pH}$ of wastewater and $B$ is dosage of Artocarpus heterophyllus coagulant (mg/L). Table 4 depicts the ANOVA analysis for this developed model. The F-value of the model obtained was 5.06 with a p-value lower than 0.05 (0.0280), which signified this model at $95 \%$ confidence level. Adequate precision which represents ratio of signalto-noise for this model was 7.342 in which the value is greater than four. This value indicated that this model could be used in navigating the design space as well. Besides, a fairly high coefficient of determination $\left(R^{2}=0.7831\right)$ was also attained. The importance of each term in the model was evaluated by testing null hypothesis. The value of $\mathrm{R}^{2}$ for any model is acceptable and indicates aptness of the model when it is greater than 0.75 [19-21]. However, adjusted $\mathrm{R}^{2}$ was lower which indicates the model used in predicting turbidity response is unsuitable and predicted values could be inaccurate [22]. The important model terms in this model were $A B, A^{2}$, and $B^{2}$.

\subsubsection{TSS Reduction}

The parameters effect on TSS reduction was examined by using CCD method. The achieved percentages of TSS reduction using parameters design matrix are displayed as in Table 3. The results illustrated that the most significant model for TSS reduction was quadratic polynomial with a moderately small p-value (0.0455), F-value (4.14) and considerably high coefficient of determination $\left(R^{2}\right)$ which was 0.7571. Adequate precision measured was (6.259) (> 4), representing signal-to-noise ratio of this model which implied that the model is applicable in navigating design space. Furthermore, lack of fit of the model was not significant at $95 \%$ significance level. Table 4 displays the ANOVA analysis for the model. The coded factors equation of the model is given by the following Equation (3):

$$
\begin{aligned}
\text { TSSreductionf }+ & 83.52-1.53 A+2.22 B-2.30 A B-1.68 A^{2} \\
& -4.80 B^{2}
\end{aligned}
$$

Where $\mathrm{A}$ is the $\mathrm{pH}$ of wastewater and $\mathrm{B}$ is dosage of Artocarpus heterophyllus coagulant (mg/L). In this model, dosage of coagulant and $\mathrm{pH}$ of wastewater were determined as effective parameters in the TSS reduction. In this experiment, $A^{2}, B^{2}$ and $A B$ were important model terms as well. The adjusted $\mathrm{R}^{2}$ was lower which indicates the model used in predicting turbidity response is unsuitable and predicted values could be inaccurate [22].

\subsubsection{COD Reduction}

Table 3 provides the percentages of COD reduction using the design array of the variables. Analysis on fitting of data was carried out with various models comprising of linear, two factorial, quadratic and cubic ones along with their respective ANOVA. Quadratic polynomial model was deduced to be the most fitting for COD reduction as well. The coded factors equation of the model is illustrated by the following Equation (4):

$$
\begin{aligned}
& \text { CODreductionf }+35.31-0.86 \mathrm{~A}-0.61 \mathrm{~B}-2.92 \mathrm{AB}- \\
& 1.04 \mathrm{~A}^{2}-0.86 \mathrm{~B}^{2}
\end{aligned}
$$

Where $\mathrm{A}$ is the $\mathrm{pH}$ of wastewater and $\mathrm{B}$ is dosage of Artocarpus heterophyllus coagulant (mg/L). The interpretation of ANOVA for this model is displayed as in Table 4. The null hypothesis test was performed to study on the importance of each remarkable term in the model. The F-value achieved by the model was 10.15 along with $\mathrm{p}$-value below than 0.05 (<0.0041). This value represents the significance of the model at the $95 \%$ confidence level. The coefficient of determination $\left(R^{2}\right)$ achieved was 0.8788 and adequate precision was attained at 8.863 which is higher than 4 for the developed model. These values demonstrates that this model can be used in navigating design space and actual relationship between the parameters.

\subsubsection{BOD Reduction}

The effect of $\mathrm{pH}$ of wastewater and coagulant dosage on the $B O D$ reduction was also evaluated by using CCD method. The achieved BOD reduction percentages is displayed as in Table 3. The ANOVA analysis for the model is displayed as in Table 4. Quadratic polynomial has been identified as the most significant model. The developed model has achieved a fairly small p-value of 0.0180 , F-value of 
6.00 and the coefficient of determination $\left(R^{2}\right)$ was 0.8109 that is comparatively high. The model can be practicable in navigating the design space as adequate precision measured was 7.160 which is greater than 4. Lack of fit was not possessed by the model at $95 \%$ significance level. Equation of the model is given by Equation (5) in the form of coded factors:

$B O D$ reduction $+37.66+0.94 A+0.025 A-0.57 A B-$

$$
2.75 A^{2}-1.79 B^{2}
$$

Where $\mathrm{A}$ is the $\mathrm{pH}$ of wastewater and $\mathrm{B}$ is dosage of Artocarpus heterophyllus coagulant (mg/L) The adjusted $\mathrm{R}^{2}$ was lower than 0.75 which indicates the model used in predicting turbidity response is unsuitable and predicted values could be inaccurate [22]. Important model terms in this case were $A^{2}, B^{2}$ and $A B$ as well.

Table 3 Experimental design and response for optimization

\begin{tabular}{ccccccc}
\hline & \multicolumn{2}{c}{ Factors } & \multicolumn{4}{c}{ Responses (removal \%) } \\
\cline { 2 - 7 } $\begin{array}{c}\text { Std } \\
\text { order }\end{array}$ & $\begin{array}{c}\text { A: } \\
\mathbf{p H} \text { of } \\
\text { wastewater } \\
(\mathbf{p H})\end{array}$ & $\begin{array}{c}\text { B: } \\
\text { Dosage of } \\
\text { coagulant } \\
(\mathbf{m g} / \mathbf{L})\end{array}$ & Turbidity & TSS & BOD & COD \\
\hline 1 & 1.5 & 55.0 & 72.1 & 70.3 & 27.4 & 32.7 \\
2 & 2.5 & 55.0 & 79.5 & 75.1 & 32.5 & 37.4 \\
3 & 1.5 & 65.0 & 78.5 & 74.8 & 30.5 & 35.5 \\
4 & 2.5 & 65.0 & 73.6 & 70.4 & 33.3 & 28.5 \\
5 & 1.0 & 60.0 & 86.3 & 83.7 & 26.9 & 33.1 \\
6 & 3.0 & 60.0 & 78.2 & 74.3 & 28.6 & 29.1 \\
7 & 2.0 & 50.0 & 60.9 & 59.8 & 32.5 & 32.1 \\
8 & 2.0 & 70.0 & 76.9 & 73.2 & 30.7 & 31.5 \\
9 & 2.0 & 60.0 & 86.4 & 87.5 & 37.4 & 36.6 \\
10 & 2.0 & 60.0 & 87.4 & 84.7 & 36.9 & 35.7 \\
11 & 2.0 & 60.0 & 83.9 & 82.1 & 40.8 & 34.3 \\
12 & 2.0 & 60.0 & 91.9 & 90.6 & 38.5 & 35.9 \\
13 & 2.0 & 60.0 & 85.5 & 81.5 & 39.1 & 33.8 \\
\hline
\end{tabular}

Table 4 Regression coefficient estimates and analysis of variance (ANOVA)

\begin{tabular}{|c|c|c|c|c|c|c|}
\hline \multicolumn{7}{|c|}{ Turbidity Removal } \\
\hline Source & $\begin{array}{c}\text { Sum of } \\
\text { squares }\end{array}$ & $\begin{array}{l}d \\
f\end{array}$ & $\begin{array}{c}\text { Mean } \\
\text { square }\end{array}$ & F-value & p-value & \\
\hline Model & 631.14 & 5 & 126.23 & 5.06 & 0.0280 & \multirow[t]{7}{*}{ Significant } \\
\hline A & 15.64 & 1 & 15.64 & 0.63 & 0.4546 & \\
\hline B & 88.02 & 1 & 88.02 & 3.53 & 0.1025 & \\
\hline$A B$ & 37.82 & 1 & 37.82 & 1.51 & 0.2582 & \\
\hline$A^{2}$ & 37.84 & 1 & 37.84 & 1.52 & 0.2580 & \\
\hline$B^{2}$ & 489.63 & 1 & 489.63 & 19.61 & 0.0031 & \\
\hline Residual & 174.78 & 7 & 24.97 & & & \\
\hline $\begin{array}{c}\text { Lack of } \\
\text { fit }\end{array}$ & 138.39 & 3 & 46.13 & 5.07 & 0.0754 & \multirow[t]{5}{*}{ Not significant } \\
\hline Pure & 36.39 & 4 & \multirow[t]{4}{*}{9.10} & & & \\
\hline Error & & & & & & \\
\hline Cor & 805.92 & 1 & & & & \\
\hline Total & & 2 & & & & \\
\hline \multicolumn{7}{|c|}{$C . V .=6.24 \% ; R^{2}=0.7831 ;$ Adjusted $R^{2}=0.6282 ;$ Adeq. Precision $=7.342$} \\
\hline \multicolumn{7}{|c|}{ TSS Removal } \\
\hline Source & $\begin{array}{l}\text { Sum of } \\
\text { squares }\end{array}$ & $\begin{array}{l}d \\
f\end{array}$ & $\begin{array}{c}\text { Mean } \\
\text { square }\end{array}$ & F-value & p-value & \\
\hline Model & 639.79 & 5 & 127.96 & 4.14 & 0.0455 & \multirow[t]{7}{*}{ Significant } \\
\hline A & 28.21 & 1 & 28.21 & 0.91 & 0.3714 & \\
\hline B & 58.96 & 1 & 58.96 & 1.91 & 0.2099 & \\
\hline$A B$ & 21.16 & 1 & 21.16 & 0.68 & 0.4355 & \\
\hline$A^{2}$ & 64.65 & 1 & 64.65 & 2.09 & 0.1915 & \\
\hline$B^{2}$ & 528.97 & 1 & 528.97 & 17.10 & 0.0044 & \\
\hline $\begin{array}{c}\text { Residua } \\
\text { | }\end{array}$ & 216.56 & 7 & 30.94 & & & \\
\hline $\begin{array}{c}\text { Lack of } \\
\text { fit }\end{array}$ & 158.59 & 3 & 52.86 & 3.65 & 0.1217 & \multirow[t]{6}{*}{$\begin{array}{c}\text { Not } \\
\text { significant }\end{array}$} \\
\hline Pure & 57.97 & 4 & 14.49 & & & \\
\hline Error & \multirow{3}{*}{856.35} & & & & & \\
\hline Cor & & 1 & & & & \\
\hline Total & & 2 & & & & \\
\hline \multicolumn{6}{|c|}{ C.V. $=7.17 \% ; R^{2}=0.7571 ;$ Adjusted $R^{2}=0.5665 ;$ Adeq. Precision $=6.259$} & \\
\hline
\end{tabular}

\begin{tabular}{|c|c|c|c|c|c|c|}
\hline \multicolumn{7}{|c|}{ BOD Removal } \\
\hline Source & $\begin{array}{c}\text { Sum of } \\
\text { squares }\end{array}$ & $\begin{array}{l}d \\
f\end{array}$ & $\begin{array}{c}\text { Mean } \\
\text { square }\end{array}$ & F-value & $p$-value & \\
\hline Model & 210.89 & 5 & 42.18 & 6.00 & 0.0180 & Significant \\
\hline A & 10.64 & 1 & 10.64 & 1.51 & 0.2582 & \\
\hline B & 0.0075 & 1 & 0.0075 & 0.0011 & 0.9748 & \\
\hline$A B$ & 1.32 & 1 & 1.32 & 0.19 & 0.6774 & \\
\hline$A^{2}$ & 173.58 & 1 & 173.58 & 24.71 & 0.0016 & \\
\hline $\mathrm{B}^{2}$ & 73.41 & 1 & 73.41 & 10.45 & 0.0144 & \\
\hline $\begin{array}{c}\text { Residua } \\
\text { I }\end{array}$ & 49.17 & 7 & 7.02 & & & \\
\hline $\begin{array}{c}\text { Lack of } \\
\text { fit }\end{array}$ & 39.76 & 3 & 13.25 & 5.63 & 0.0641 & $\begin{array}{c}\text { Not } \\
\text { significant }\end{array}$ \\
\hline Pure & 9.41 & 4 & 2.35 & & & \\
\hline Error & & & & & & \\
\hline Cor & 260.07 & 1 & & & & \\
\hline Total & & 2 & & & & \\
\hline \multicolumn{7}{|c|}{ C.V. $=7.92 \% ; R^{2}=0.8109 ;$ Adjusted $R^{2}=0.6759 ;$ Adeq. Precision $=7.160$} \\
\hline \multicolumn{7}{|c|}{ COD Removal } \\
\hline Source & $\begin{array}{c}\text { Sum of } \\
\text { squares }\end{array}$ & $\begin{array}{l}d \\
f\end{array}$ & $\begin{array}{c}\text { Mean } \\
\text { square }\end{array}$ & F-value & $\mathrm{p}$-value & \\
\hline Model & 80.18 & 5 & 16.04 & 10.15 & 0.0041 & Significant \\
\hline A & 8.84 & 1 & 8.84 & 5.60 & 0.0499 & \\
\hline B & 4.44 & 1 & 4.44 & 2.81 & 0.1375 & \\
\hline$A B$ & 34.22 & 1 & 34.22 & 21.67 & 0.0023 & \\
\hline$A^{2}$ & 24.64 & 1 & 24.64 & 15.60 & 0.0055 & \\
\hline$B^{2}$ & 17.03 & 1 & 17.03 & 10.78 & 0.0134 & \\
\hline $\begin{array}{c}\text { Residua } \\
\text { । }\end{array}$ & 11.06 & 7 & 1.58 & & & \\
\hline $\begin{array}{c}\text { Lack of } \\
\text { fit }\end{array}$ & 5.60 & 3 & 1.87 & 1.37 & 0.3723 & $\begin{array}{c}\text { Not } \\
\text { significant }\end{array}$ \\
\hline $\begin{array}{l}\text { Pure } \\
\text { Error }\end{array}$ & 5.45 & 4 & 1.36 & & & \\
\hline Cor & 91.23 & 1 & & & & \\
\hline Total & & 2 & & & & \\
\hline C.V. $=3.7$ & $; R^{2}=0.878$ & & $e d R^{2}=0$ & 3 ; Adeq. & ision $=8$ & \\
\hline
\end{tabular}

\subsection{Effect of Parameters}

The effect of $\mathrm{pH}$ of wastewater and dosage of coagulant dosage and their interactions with the turbidity reduction is illustrated in Figure 1 (a) and 1 (b) by using the $3 \mathrm{D}$ response surface plot and contour plot at $\mathrm{pH} 2$ and dosage of coagulant at $60 \mathrm{mg} / \mathrm{L}$ (center point). A change in the coagulant dosage and $\mathrm{pH}$ of wastewater are effective factors in the turbidity reduction of wastewater in application of natural coagulant for the treatment $[9,23]$. The percentage of turbidity reduction increased by enhancing dosage of coagulant up to $60 \mathrm{mg} / \mathrm{L}$ at $\mathrm{pH}$ 2. The percentage of reduction then decreased from $87.4 \%$ to $72.1 \%$ using $55 \mathrm{mg} / \mathrm{L}$ of coagulant and 60.9 $\%$ using $50 \mathrm{mg} / \mathrm{L} \mathrm{at} \mathrm{pH}$ 2. The usage of Ocimum basilicum seed for textile wastewater treatment was reported by Shamsnejati et al. have reported and observed that maximum COD reduction was at $\mathrm{pH}$ 6.5 which is in acidic condition [24]. Besides, okra mucilage has also been tested on textile wastewater and was discovered that significant reduction obtained at $\mathrm{pH}$ 5. Freitas et al. studied on reduction of COD and BOD and revealed that removal percentage achieved were $48 \%$ and $92 \%$ respectively at acidic condition [25].

These results were interpreted based on the contour diagram generated after the optimization process. Figure 1(c) and 1(d) display the effect of coagulant dosage and $\mathrm{pH}$ of wastewater and their interaction with the TSS reduction based on 3D surface plots. The percentage of TSS reduction decreased from $90.6 \%$ to $73.2 \%$ when the dosage is raised from $60 \mathrm{mg} / \mathrm{L}$ to $70 \mathrm{mg} / \mathrm{L}$. The percentage of TSS reduction obtained with $50 \mathrm{mg} / \mathrm{L}$ was only $59.8 \%$. 
The maximum TSS reduction was achieved at $\mathrm{pH} 2$ and dosage of $60 \mathrm{mg} / \mathrm{L}$, similar to turbidity reduction. Both the turbidity and TSS percentage were reduced to the maximum at $\mathrm{pH}$ of 2 . Figure $1(\mathrm{e})$ and $1(\mathrm{f})$ represent percentage reduction of COD in the wastewater. The percentage of reduction increased as the dosage is increased from $50 \mathrm{mg} / \mathrm{L}$ to $55 \mathrm{mg} / \mathrm{L}$. The reduction is raised from $28.5 \%$ to $37.4 \%$ at $\mathrm{pH} 2.5$. However, the efficiency of the coagulant decreased when the dosage was further increased to $65.0 \mathrm{mg} / \mathrm{L}$ where the reduction achieved was only $29.1 \%$. Figure $1(\mathrm{~g})$ and $1(\mathrm{~h})$ demonstrate the plot of percentage reduction of BOD with the effect of dosage of coagulant and $\mathrm{pH}$ of wastewater. The maximum BOD reduction was achieved at dosage of $60.0 \mathrm{mg} / \mathrm{L}$ with reduction of $40.8 \%$. The percentage of reduction reduced up to $26.9 \%$ when the dosage was increased up to $60 \mathrm{mg} / \mathrm{L}$.

It is significant to identify the optimum dosage of coagulant as to reduce dosing cost and sludge volume after the treatment process [12]. The addition of natural coagulant increased the aggregation among particles that collide with each other. Thus, efficiency of coagulation increases when optimum coagulant dosage is applied whereas dropped in efficiency can be observed with increase of dosage beyond the optimum level. The aggregated particles re-disperse and disturb the settling process of particle above the optimum amount of coagulant [26].As for the acidic condition of the $\mathrm{pH}$ of wastewater, the suspension undergoes destabilization as the particle surface charge is either neutralized or reduced at optimum $\mathrm{pH}$. Destabilization of particles leads to the coagulation process in forming larger colloids that settled to the bottom of wastewater. It is presumed that Artocarpus heterophyllus possessed the mechanism of bridging effect and charge neutralization. This fruit peel contains of different components that comprises of various functional groups. This functional groups that carry different charges possibly enable the particles to attach one another with the charge being neutralized. The optimum $\mathrm{pH}$ for the maximum turbidity and colour removal by chitosan was obtained to be $\mathrm{pH} 3$. It was described that at lower $\mathrm{pH}$ values, morphology of the polymeric chains widen whereas the hydrodynamic radius will increase. This is linked to the reduction of electrostatic repulsion force due to the presence of cationic polyelectrolyte molecules that enhance the bridging effect between particles of natural coagulant and colloids [23].

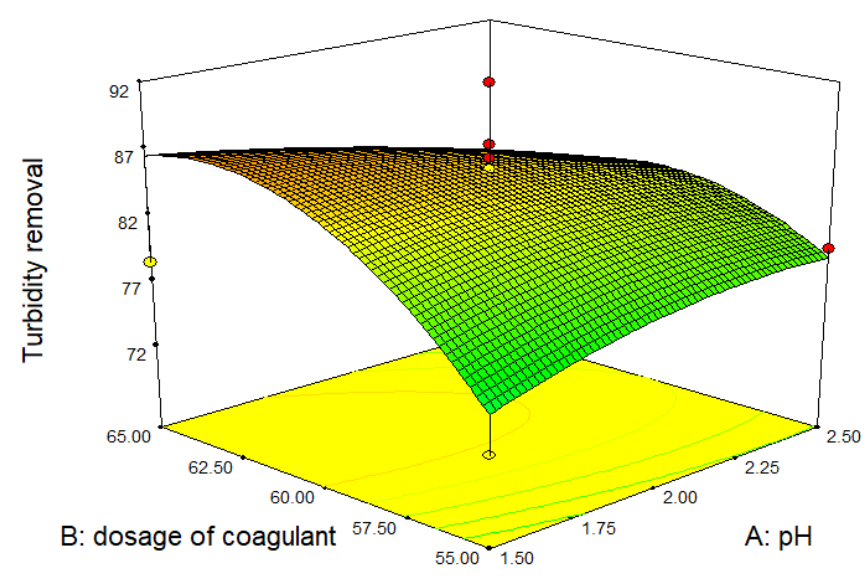

(a)

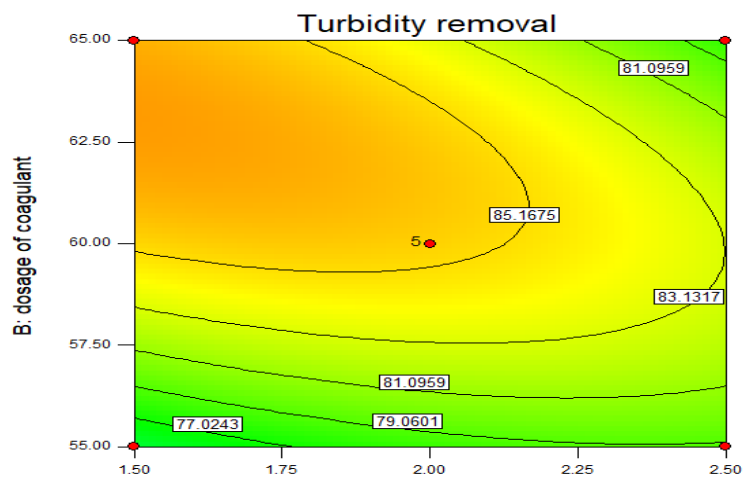

A: $\mathrm{pH}$

(b)

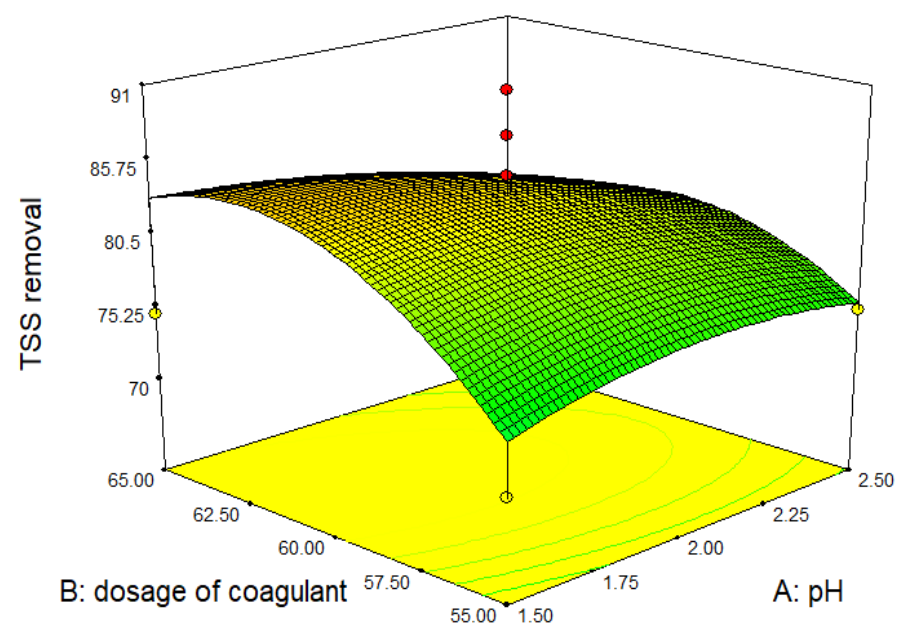

(c) 


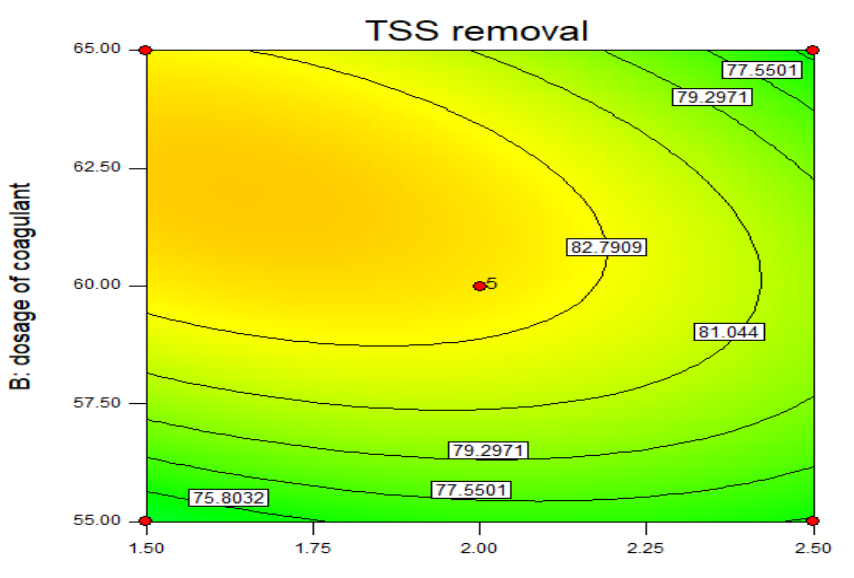

$\mathrm{A}: \mathrm{pH}$

(d)

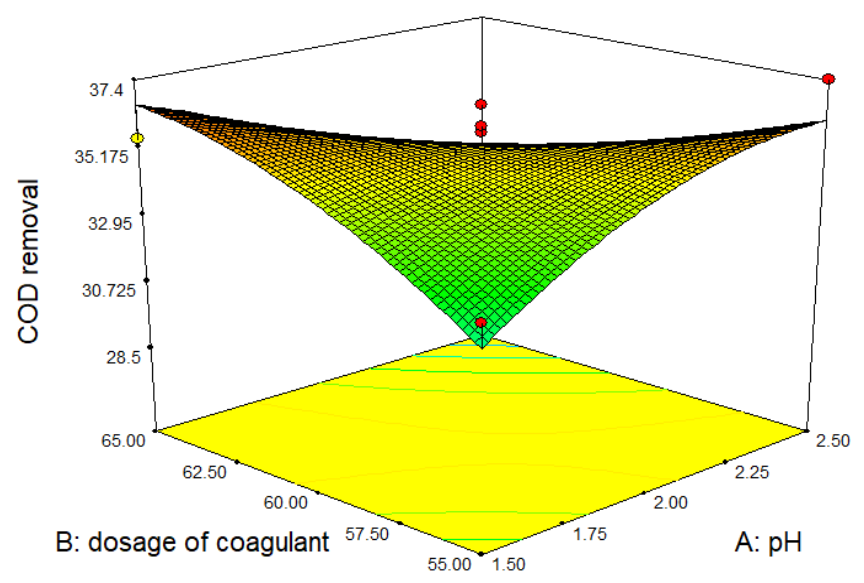

(e)

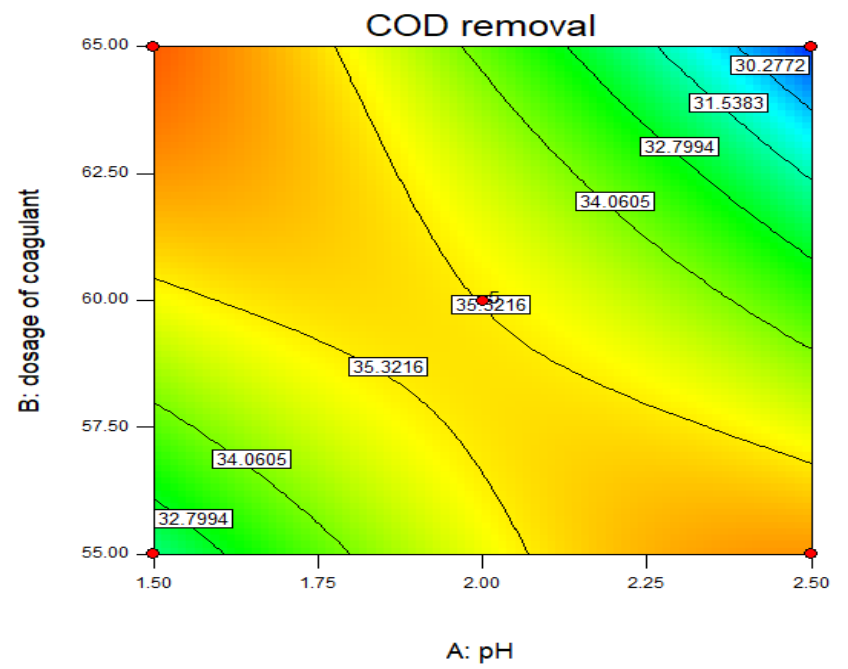

(f)

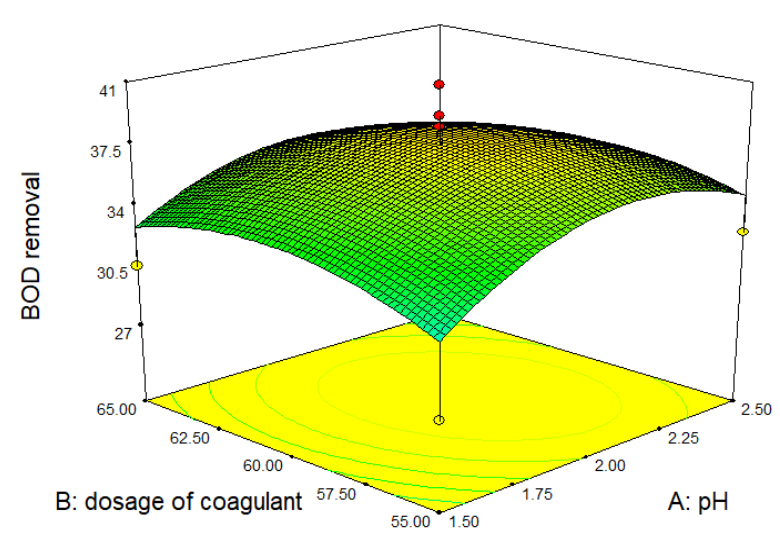

(g)

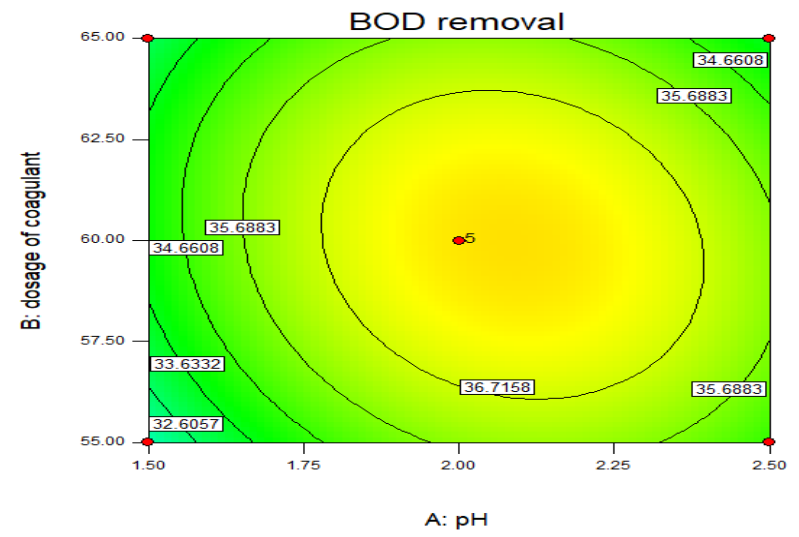

(h)

Figure 1 Response surface plots displaying the interaction between two parameters dosage of coagulant and $\mathrm{pH}$ of wastewater in turbidity $(a, b), \operatorname{TSS}(c, d), \operatorname{COD}(e, f)$ and BOD $(g, h)$ reduction of synthetic domestic wastewater

\subsection{Validation Run for Optimization Process}

In order to confirm the optimum turbidity, TSS, COD and BOD removal efficiency conditions, three additional experiments were performed using conditions predicted by the Design Expert. The validation experiments were carried out in triplicates at pH 2.1 and dosage of coagulant at $58 \mathrm{mg} / \mathrm{L}$. The values of the optimum condition are as shown in Table 5. This results showed the validity of response model. Moreover, the errors from these validation runs were in between $0 \%$ to $4.0 \%$ which is in good agreement with the predicted values with error less than $10 \%$. Hejazi et al. have discussed on experimental design optimization utilizing response surface methodology in which a percentage error below $10 \%$ is generally acceptable due to the nature of the experiment involving several fluctuating variables. At the same time, the experimental values must be within the $95 \%$ prediction intervals of the model [27]. The experimental versus predicted values graph is presented in Figure 2. As can be seen from 
Figure 2, the data points are distributed fairly close and have linear behavior which indicates adequate agreement between predicted and experimental data.

Table 5 Validation experiments for turbidity removal

\begin{tabular}{|c|c|c|c|c|c|}
\hline \multicolumn{2}{|l|}{ Condition } & \multirow{3}{*}{$\begin{array}{l}\text { Turbidity } \\
\text { (\%) }\end{array}$} & \multirow{3}{*}{$\begin{array}{l}\text { TSS } \\
\text { (\%) }\end{array}$} & \multirow{3}{*}{$\begin{array}{l}C O D \\
(\%)\end{array}$} & \multirow{3}{*}{$\begin{array}{c}B O D \\
(\%)\end{array}$} \\
\hline $\mathrm{pH}$ of wastewater & 2.1 & & & & \\
\hline $\begin{array}{l}\text { Dosage of } \\
\text { coagulant (mg/L) }\end{array}$ & 58 & & & & \\
\hline $\begin{array}{l}\text { Predicted } \\
\text { removal }\end{array}$ & - & 83.4 & 81.4 & 35.5 & 37.4 \\
\hline $\begin{array}{l}\text { Experimental } \\
\text { removal }\end{array}$ & - & $\begin{array}{c}80.7 \pm \\
0.4\end{array}$ & $\begin{array}{c}77.5 \pm \\
0.5\end{array}$ & $34.6 \pm 0.8$ & $\begin{array}{c}34.3 \pm \\
0.5\end{array}$ \\
\hline Percentage of error & - & 2.7 & 3.9 & 0.9 & 3.1 \\
\hline
\end{tabular}

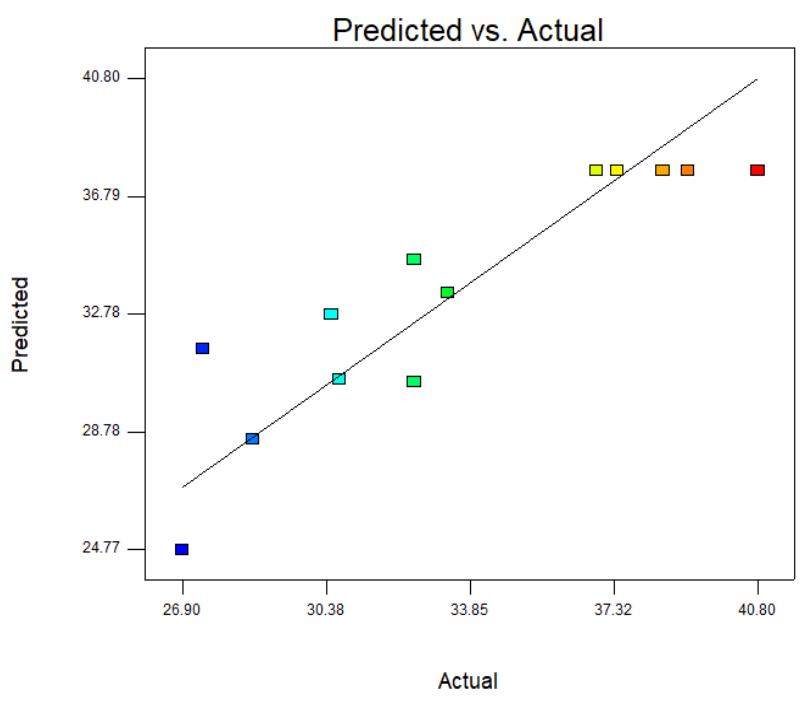

(a)

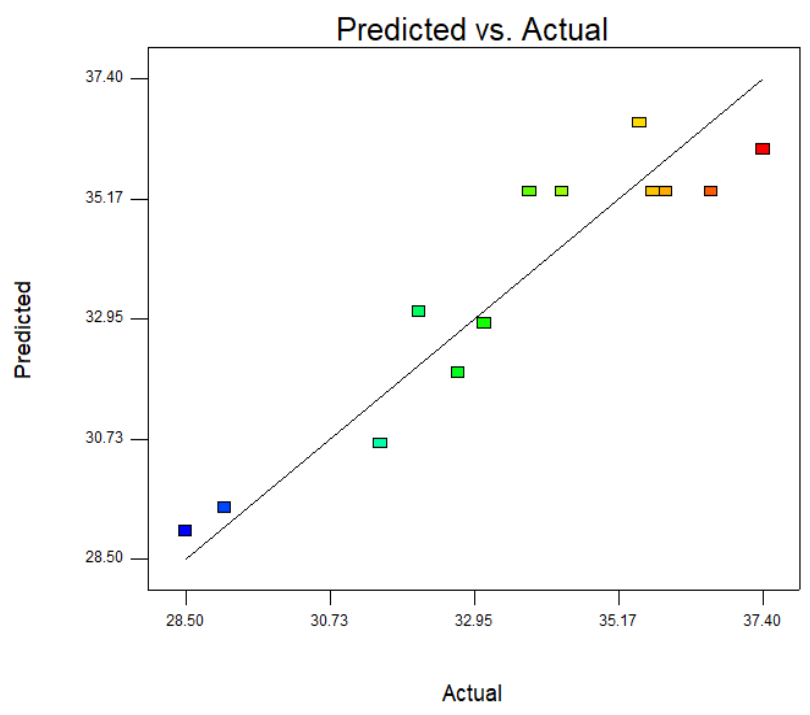

(b)

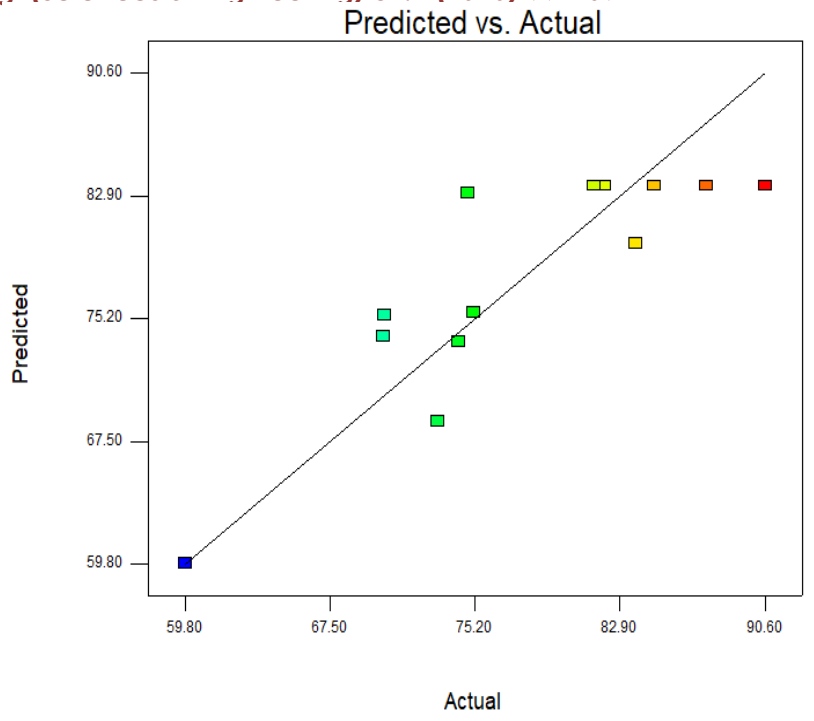

(c)

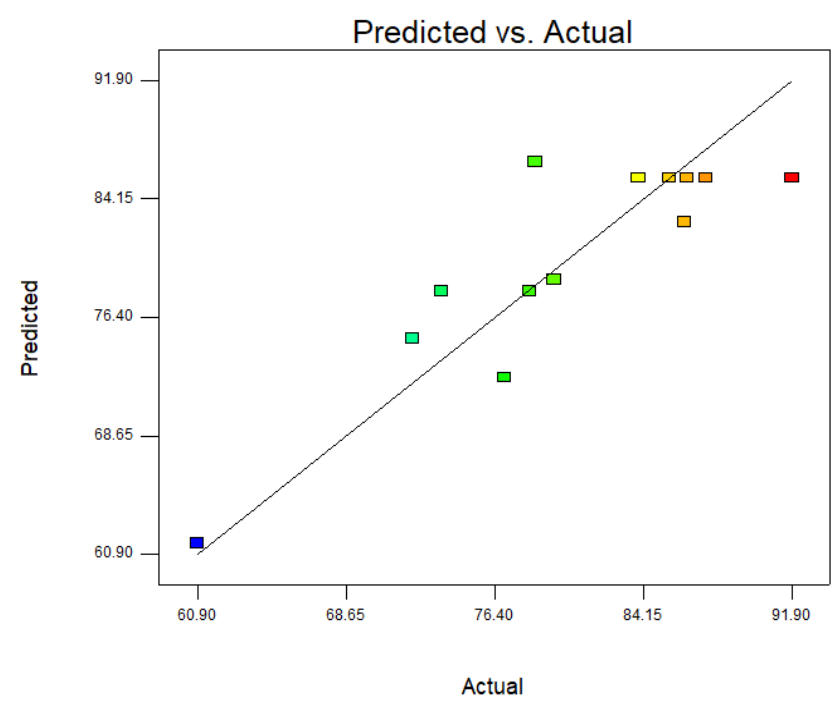

(d)

Figure 2 Predicted versus actual for optimization of (a) COD removal (b) BOD removal (c) TSS removal and (d) turbidity removal

\subsection{Characterization of Coagulant}

The FTIR spectrum as in Figure 3 detected presence of different functional groups in Artocarpus heterophyllus peel extract coagulant including carboxyl $(\mathrm{C}=\mathrm{O})$, hydroxyl $(\mathrm{O}-\mathrm{H})$ and amine $(\mathrm{N}-\mathrm{H})$ groups. Literature studies, revealed that hydroxyl (O$\mathrm{H})$, carboxyl $(\mathrm{C}=\mathrm{O})$, and amino or amide $(-\mathrm{NH} 2)$ groups as well as hydrogen bonding were the preferred groups for the coagulation-flocculation process [28-32]. The zeta potential analysis demonstrated surface charge of the synthetic wastewater was positive at $\mathrm{pH} 2$ and later turned to be negative as the $\mathrm{pH}$ is increased $\mathrm{up}$ to $\mathrm{pH} 12$ as in Figure 4. The surface charge of coagulant was identified to be $-25.2 \mathrm{mV}$ at its original $\mathrm{pH}, 6.95$. Opposite surface charges of the particles in 
wastewater and coagulant contributes to the effectiveness of the coagulant [33] which revealed that this coagulant is more effective within the acidic range. It can also be deduced that Artocarpus heterophyllus peel coagulant possessed the characteristic of anionic polyelectrolytes where the primary mechanism involved in the aggregation of the constituents was charge neutralization as well as bridging mechanism assisted by the presence of functional groups as identified.

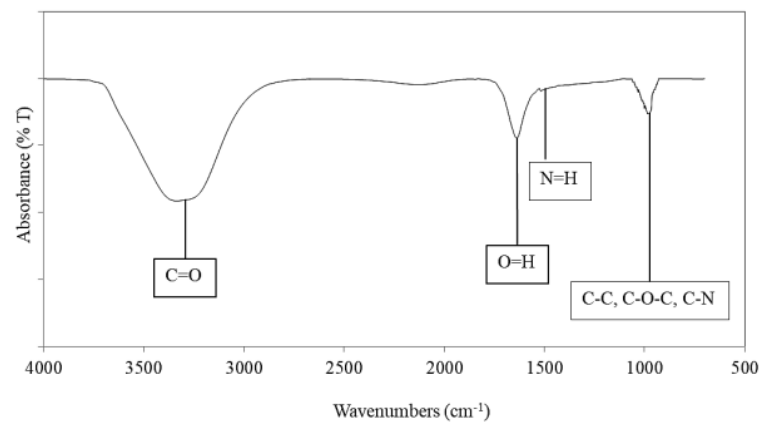

Figure 3 FTIR analysis of Artocarpus heterophyllus peel extracted with distilled water

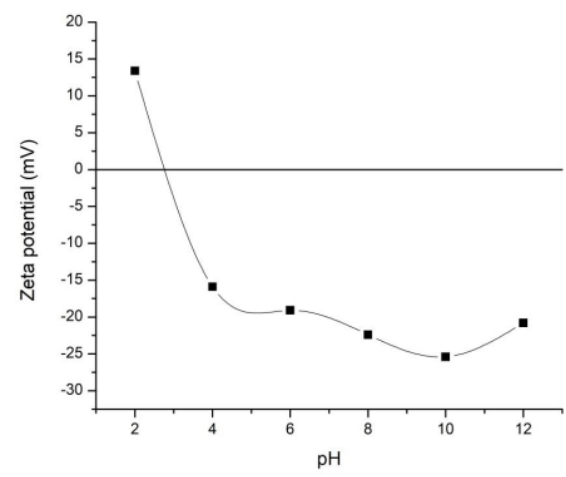

Figure $\mathbf{4}$ Variations of zeta potential of synthetic wastewater with respect to $\mathrm{pH}$

\subsection{CONCLUSION}

Artocarpus heterophyllus has been identified as effective natural coagulant in treating wastewater. Response surface methodology (RSM) involving central composite design (CCD) was efficiently implemented in optimizing the removal parameters. The maximum reduction of turbidity, TSS, BOD and COD were achieved at $\mathrm{pH} 2.1$ and dosage of 58 $\mathrm{mg} / \mathrm{L}$. All of these results were fairly equivalent with predicted values with optimum conditions as obtained in validation experiment. The results obtained implies that this bio-based coagulant can be used in pre-treatment of wastewater to reduce the usage of chemical coagulant. Further studies are suggested in applying this natural coagulant for other types of wastewater.

\section{Acknowledgement}

The authors would like to acknowledge the financial support provided by Ministry of Education Malaysia under FRGS Grant: FRGS/1/2017/TK02/UMP/02/14. Sincere gratitude also expressed to Universiti Malaysia Pahang (UMP) for providing PGRS190375 and MRS scholarship.

\section{References}

[1] Singh, R. 2015. Membrane Technology and Engineering for Water Purification. Second Edition. Oxford: Butterworth-Heinemann.

[2] Al-Hamadani, Y. A. J., Suffian Yusoff, M., Umar, M., Bashir, M. J. K., and Nordin Adlan, M. 2011. Application of Psyllium Husk as Coagulant and Coagulant Aid in Semiaerobic Landfill Leachate Treatment. J. Hazard. Mater. 190: 582-587.

[3] Tawakkoly, B., Alizadehdakhel, A., and Dorosti, F. 2019. Evaluation of COD and Turbidity Removal from Compost Leachate Wastewater using Salvia hispanica as a Natural Coagulant. Industrial Crops and Products. 137: 323-331.

[4] Yin, C. Y. 2010. Emerging Usage of Plant-based Coagulants for Water and Wastewater Treatment. Process Biochem. 45: 1437-1444.

[5] Patale, V. and Pandya, J. 2012. Mucilage Extract of Coccinia Indica Fruit as Coagulant-flocculent for Turbid Water Treatment. Asian J. Plant. Sci. Res. 2: 442-445.

[6] Bratby, J. 2016. Coagulation and Flocculation in Water and Wastewater Treatment. IWA Publishing.

[7] Budd, C. G., Hess, F. A., Shorney-Darby, H., Neemann, J. J., Spencer, M. C., Bellamy, D. J., and Hargette, H. P. 2004. Coagulation Applications for New Treatment Goals. American Water Works Association. 96: 102-113.

[8] Adesina, O. A., Abdulkareem, F., Yusuff, A. S., Lala, M., and Okewale, A. 2019. Response Surface Methodology Approach to Optimization of Process Parameter for Coagulation Process of Surface Water Using Moringa Oleifera Seed. South African Journal of Chemical Engineering. 28: 46-51.

[9] Kakoi, B., Kaluli, J. W., Ndiba, P., and Thiong'o, G. 2017. Optimization of Maerua Decumbent Bio-coagulant in Paint Industry Wastewater Treatment with Response Surface Methodology. Journal of Cleaner Production. 164: 1124-1134.

[10] Khataee, A., Kasiri, M., and Alidokht, L. 2011. Application of Response Surface Methodology in the Optimization of Photocatalytic Removal of Environmental Pollutants Using Nanocatalysts. Environmental technology. 32(15): 1669-1684.

[11] Paula, H. M., Oliveira llha, M. S., Sarmento, A. P., and Andrade, L. S. 2018. Dosage optimization of Moringa Oleifera Seed and Traditional Chemical Coagulants Solutions for Concrete Plant Wastewater Treatment. Journal of Cleaner Production. 174: 123-132.

[12] Subramonian, W., Wu, T. Y., and Chai, S. P. 2015. An Application of Response Surface Methodology for Optimizing Coagulation Process of Raw Industrial Effluent Using Cassia Obtusifolia Seed Gum Together with Alum. Industrial Crops and Products. 70: 107-115.

[13] Wan, J., Chakraborty, T., XU, C., and Ray, M. B. 2019. Treatment Train for Tailings Pond Water using Opuntia Ficus-indica as Coagulant. Separation and Purification Technology. 211: 448-455.

[14] Huzir, N. M., Aziz, M. M. A., Ismail, S. B., Mahmood, N. A. N., Umor, N. A., and Faua'ad Syed Muhammad, S. A. 2019. Optimization of Coagulation-flocculation Process 
for the Palm Oil Mill Effluent Treatment by Using Rice Husk Ash. Industrial Crops and Products. 139: 111-482.

[15] Shak, K. P. Y., and WU, T. Y. 2015. Optimized Use of Alum Together with Unmodified Cassia Obtusifolia Seed Gum as a Coagulant Aid in Treatment of Palm Oil Mill Effluent Under Natural Ph of Wastewater. Industrial Crops and Products. 76: $1169-1178$.

[16] Kutty, S., Isa, M., and Leong, L. 2011. Removal of Ammonia-nitrogen (NH3-N) and Nitrate (NO3-) by Modified Conventional Activated-sludge System to Meet New DOE Regulations. International Proceedings of Chemical, Biological and Environmental Engineering. 103-107.

[17] Prieto, A. L. 2019. Sequential Anaerobic and Algal Membrane Bioreactor (A2MBR) System for Sustainable Sanitation and Resource Recovery from Domestic Wastewater. Environ. Sci.: Water Res. Technol. 5: 16611671

[18] FAO, U. 2012. Food Outlook: Global Market Analysis. Rome, Italy.

[19] Cui, L., Ouyang, Y., Lou, Q., Yang, F., Chen, Y., Zhu, W. and Luo, S. 2010. Removal of Nutrients from Wastewater with Canna indica L. under Different Vertical-flow Constructed Wetland Conditions. Ecological Engineering. 36: 1083-1088

[20] El-naggar, N. E., Hamouda, R. A., Mousa, I. E., Abdelhamid, M. S. and Rabei, N. H. 2018. Biosorption Optimization, Characterization, Immobilization and Application of Gelidium amansii Biomass for Complete Pb 2 + Removal from Aqueous Solutions. Sci. Rep. 8: 1-19.

[21] Le Man, H., Behera, S. K. and Park, H. S. 2010. Optimization of Operational Parameters for Ethanol Production from Korean Food Waste Leachate. Int. J. Environ. Sci. Technol. 7: 157-164.

[22] Choong Lek, B. L., Peter, A. P., Qi Chong, K. H., Ragu, P. Sethu, V., Selvarajoo, A., and Arumugasamy, S. K. 2018. Treatment of Palm Oil Mill Effluent (POME) using chickpea (Cicer arietinum) as a Natural Coagulant and Flocculant: Evaluation, Process Optimization and Characterization of Chickpea Powder. Journal of Environmental Chemical Engineering. 6(5): 6243-6255.

[23] Momeni, M. M., Kahforoushan, D., Abbasi, F., and Ghanbarian, S. 2018. Using Chitosan/CHPATC as Coagulant to Remove Color and Turbidity of Industrial Wastewater: Optimization through RSM Design. Journal of Environmental Management. 21 1: 347-355.
[24] Shamsnejati, S., Chaibakhsh, N., Pendashteh, A. R., and Hayeripour, S. 2015. Mucilaginous Seed of Ocimum basilicum as a Natural Coagulant for Textile Wastewater Treatment. Industrial Crops and Products. 69: 40-47.

[25] Freitas, Oliveira, V. M., de Souza, M. T. F., Geraldino, H. C. L., Almeida, V. C., Fávaro, S. L., and Garcia, J. C. 2015. Optimization of Coagulation-flocculation Process for Treatment of Industrial Textile Wastewater using okra (A. esculentus) Mucilage as Natural Coagulant. Industrial Crops and Products. 76: 538-544.

[26] Teh, C. Y., and WU, T. Y. 2014. The Potential Use of Natural Coagulants and Flocculants in the Treatment of Urban Waters. Chemical Engineering Transaction. 16031608.

[27] Hejazi, T. H., Bashiri, M., DI'az-Garci'a, J. A. and Noghondarian, K. 2012. Optimization of Probabilistic Multiple Response Surfaces. Appl. Math. Model. 36: 12751285

[28] Guo, J., Yang, C., and Zeng, G. 2013. Treatment of Swine Wastewater Using Chemically Modified Zeolite and Bioflocculant from Activated Sludge. Bioresource Technology. 143: 289-297

[29] Li, Z., Chen, R.-W., Lei, H.-Y., Shan, Z., Bai, T., Yu, Q., and Li, H.-L. 2008. Characterization and Flocculating Properties of a Novel Bioflocculant Produced by Bacillus circulans. World Journal of Microbiology and Biotechnology. 25(5): 745.

[30] Liu, H., Hu, C., Zhao, H., and Qu, J. 2009. Coagulation of Humic Acid by PACl with High Content of All3: The Role of Aluminum Speciation. Separation and Purification Technology. 70(2): 225-230.

[31] Zhang, X., Sun, J., Liu, X. and Zhou, J. 2013. Production and Flocculating Performance of Sludge Bioflocculant from Biological Sludge. Bioresource Technology. 146: 51 56.

[32] Zhang, Z., Tao, F., Du, J., Shi, P., Yu, D., Meng, Y., and Sun, Y. 2010. Surface Water Quality and Its Control in a River with Intensive Human Impacts-A Case Study of the Xiangjiang River, China. Journal of Environmental Management. 91 (12): 2483-2490.

[33] Jiao, R., Fabris, R., Chow, C. W. K., Drikas, M., van Leeuwen, J., Wang, D. and XU, Z. 2017. Influence of Coagulation Mechanisms and Floc Formation on Filterability. Journal of Environmental Science. 57: 338345. 